\title{
Comparative Study of Deoxyribonucleic Acid Homology and Physiological Characteristics of Strains of Peptococcus saccharolyticus
}

\author{
JORGE H. CROSA, ' BETSY L. WILLIAMS, ${ }^{2}$ JULIUS J. JORGENSEN, ${ }^{2}$ AND CHARLES A. EVANS ${ }^{1}$ \\ Department of Microbiology and Immunology ${ }^{1}$ and Department of Periodontics, ${ }^{2}$ University of Washington, \\ Seattle, Washington 98195
}

\begin{abstract}
Polynucleotide sequence relationships among strains of Peptococcus saccharolyticus were assessed by analysis of deoxyribonucleic acid-deoxyribonucleic acid homo and heteroduplexes with endonuclease S1. The results showed that $P$. saccharolyticus strains isolated from different subjects form a very tight group, with deoxyribonucleic acid homology levels ranging between 93 and $100 \%$. Physiological tests of 23 strains included 30 different substrates. Results were remarkably uniform. All 23 strains grew better anaerobically with added $\mathrm{H}_{2}$ and $\mathrm{CO}_{2}$ than aerobically. However, colony size was greater on blood agar but not Trypticase soy (BBL Microbiology Systems, Cockeysville, Md.)-yeast extract agar with an atmosphere of $4 \% \mathrm{O}_{2}$ with added $\mathrm{H}_{2}$ and $\mathrm{CO}_{2}$ than with anaerobic incubation. The data suggest that these strains are sufficiently closely related to justify their inclusion in a single discrete species, but their appropriate generic classification remains to be resolved.
\end{abstract}

In two previous publications $(3,4)$ we reported that Peptococcus saccharolyticus was a numerically important part of the microbial flora of the skin of the foreheads and arms of $20 \%$ of the subjects studied, and we described the characteristics of strains isolated from these sources. Although this organism was originally described as isolated from human skin (5), it has not been generally recognized as a part of the normal flora, and its very existence has been ignored to the point that it is not even included in the latest edition of Bergey's Manual of Determinative Bacteriology (9). To determine whether the strains identified by us as $P$. saccharolyticus are sufficiently closely related to justify their inclusion in a single discrete species, we carried out further studies of metabolic activities and deoxyribonucleic acid (DNA) relatedness among $P$. saccharolyticus strains chosen as representative of different sources and different times in our study. The results show an exceptionally high level of agreement in the biochemical activities and a high degree of DNA homology.

\section{MATERIALS AND METHODS}

Bacterial strains. The sources and designations of the 23 strains used in this study are shown in Table 1. Strain ATCC 14953, the type strain of this species, was isolated 25 years before any of the other strains in this study. It was the reference strain in our studies of DNA homology. The other strains were obtained from the normal skin of nine subjects by gently swabbing the skin surface or by scrubbing the skin with a blunt Teflon rod (3). Initial cultivation was on an agar medium containing 3\% Trypticase soy broth (BBL Microbiology Systems, Cockeysville, Md.), 1\% yeast extract, and $0.5 \%$ Tween 80 (polysorbate 80; Atlas Chemical, Wilmington, Del.). These organisms ranged in population density from fewer than 100 to more than 25,000 cells per $\mathrm{cm}^{2}$ of skin, and they constituted from 1.5 to $97 \%$ of the bacteria detected in the sample.

Physiological characteristics. The 23 isolates of $P$. saccharolyticus were subjected to an extensive battery of taxonomic tests. Analyses of the cultural characteristics of these strains have been reported previously (4). Streak plates with Columbia blood agar were used for a comparison of growth in different gaseous atmospheres. After 4 days of incubation, the diameters of three to five well-isolated colonies in each culture were recorded (Table 2 ).

The inoculum for all biochemical tests was from a 3-day-old culture in prereduced, anaerobically sterilized peptone-yeast extract medium with Tween 80 , as formulated at the Virginia Polytechnic Institute and described by Holdeman et al. (6). Inocula of 1.5 to 2.0 ml were suspended in $100 \mathrm{ml}$ of the same basal medium immediately after the latter had been autoclaved and cooled to room temperature. A 2-ml amount of the suspended inoculum was then aseptically dispensed into culture tubes previously autoclaved with $0.2 \mathrm{ml}$ of a $10 \times$ concentrate of substrate in distilled water. A 0.5-ml amount of inoculum was added to a medium containing $5 \mathrm{ml}$ of milk and $5 \mathrm{ml}$ of gelatin medium prepared by the Virginia Polytechnic Institute method (6). Culture tubes were incubated under an anaerobic atmosphere (10\% hydrogen, $10 \%$ carbon dioxide, and $80 \%$ nitrogen) achieved by evacuation and replacement. Residual oxygen was removed by palladium catalyst. After incubation at $35^{\circ} \mathrm{C}$ for 4 days, acid production from carbohydrates was measured with a pH meter (model 3550; Beckman Instruments, Inc., 
TABLE 1. Bacterial strains and sources

\begin{tabular}{|c|c|c|c|c|c|c|}
\hline Strain & $\begin{array}{c}\text { Age of } \\
\text { subject } \\
\text { (years) }^{a}\end{array}$ & Site $^{b}$ & Date $^{c}$ & $\begin{array}{l}\text { Atmos- } \\
\text { phere }\end{array}$ & $\begin{array}{c}\text { Concn (CFU/ } \\
\left.\mathrm{cm}^{2}\right)^{e}\end{array}$ & $\begin{array}{l}\% \text { of } \\
\text { total }^{f}\end{array}$ \\
\hline $3-0-1$ & 61 & DEL & 10 August 1973 & $\mathbf{H}$ & 465 & 76 \\
\hline $3-0-2$ & 31 & FH & 12 January 1973 & $\mathbf{H}$ & $-^{g}$ & - \\
\hline $3-0-3$ & 30 & FH & 18 July 1973 & $\mathrm{H}$ & 12,500 & 24 \\
\hline $3-0-6$ & 29 & FH & 13 February 1973 & $\mathrm{H}$ & 275 & 10 \\
\hline $3-0-8$ & 31 & FH & 18 July 1973 & $\mathbf{H}$ & 21,500 & 92 \\
\hline $3-0-9$ & 32 & $\mathrm{FH}$ & 19 November 1974 & OX & 26,000 & 97 \\
\hline $3-0-12$ & 30 & DEL & 26 November 1973 & $\mathrm{H}$ & 50 & 13 \\
\hline $3-0-15$ & 30 & SCAP & 26 November 1973 & OX & 250 & 18 \\
\hline $3-0-16$ & 30 & SCAP & 26 November 1973 & $\mathrm{H}$ & 375 & 19 \\
\hline $3-0-17$ & 25 & $\mathrm{FH}$ & 9 April 1973 & $\mathbf{H}$ & 90 & 18 \\
\hline $3-0-18$ & 30 & $\mathrm{FH}$ & 9 January 1974 & OX & 775 & 77 \\
\hline $3-0-19$ & 63 & SCAP & 30 December 1975 & $\mathrm{H}$ & 800 & 88 \\
\hline $3-0-20$ & 63 & SCAP & 30 December 1975 & $\mathrm{OX}$ & 210 & 82 \\
\hline $3-0-21$ & - & FH & 26 March 1976 & $\mathbf{H}$ & - & - \\
\hline $3-0-22$ & - & FH & 26 March 1976 & $\mathbf{H}$ & - & - \\
\hline $3-0-23$ & 63 & ACF & 30 December 1975 & $\mathrm{H}$ & 7,500 & 88 \\
\hline $3-0-24$ & 31 & FH & 2 December 1976 & OX & 4,700 & 4 \\
\hline $3-0-25$ & 31 & FH & 2 December 1976 & OX & 4,700 & 4 \\
\hline $3-0-27$ & 65 & ACF & 10 March 1977 & OX & 124 & 88 \\
\hline $3-0-28$ & 25 & FH & 27 May 1977 & OX & 50,000 & 35 \\
\hline $3-0-29$ & 25 & FH & 27 May 1977 & $\mathrm{H}$ & 12,000 & - \\
\hline $3-0-30$ & 50 & $\mathrm{FH}$ & 27 May 1977 & $\mathrm{H}$ & 6,000 & 1.5 \\
\hline ATCC 14953 & $<35$ & $\mathrm{AR}$ & 1948 & $\mathbf{H}$ & - & - \\
\hline
\end{tabular}

${ }^{a}$ All subjects were male.

${ }^{b}$ Normal skin from the following sites: DEL, deltoid area; FH, forehead; SCAP, scapular area; ACF, antecubital fossa; AR, arm.

'Date of skin culture.

${ }^{d} \mathrm{H}$, Anaerobic (hydrogen); OX, aerobic (oxygen).

${ }^{e}$ Number of colony-forming units (CFU) of $P$. saccharolyticus per square centimeter of skin in that specimen, as shown by the anaerobic or aerobic culture from which the strain was derived.

${ }^{f} P$. saccharolyticus constituted this percentage of the total colony-forming units of the anaerobic or aerobic culture from which it was derived.

f - Data not available.

TABLE 2. Colony size as a function of atmosphere

\begin{tabular}{|c|c|c|c|c|c|c|c|c|}
\hline \multirow{2}{*}{ Atmosphere } & \multicolumn{5}{|c|}{ No. of colonies in the following size classes: } & \multirow{2}{*}{$\begin{array}{c}\text { Median } \\
\text { colony } \\
\text { size } \\
(\mathrm{mm})\end{array}$} & \multirow{2}{*}{$\begin{array}{l}\text { Total } \\
\text { no. of } \\
\text { strains }\end{array}$} & \multirow{2}{*}{$\begin{array}{l}\text { Total } \\
\text { no. of } \\
\text { colonies }\end{array}$} \\
\hline & $0.1-0.4 \mathrm{~mm}$ & $0.5-0.6 \mathrm{~mm}$ & $0.7-1.0 \mathrm{~mm}$ & $1.1-2.0 \mathrm{~mm}$ & $>2.0 \mathrm{~mm}$ & & & \\
\hline Air & 25 & 25 & 16 & 0 & 0 & 0.5 & 17 & 66 \\
\hline $\mathrm{Air}+10 \% \mathrm{CO}_{2}$ & 37 & 17 & 14 & 0 & 0 & 0.35 & 19 & 68 \\
\hline $\begin{array}{l}10 \% \mathrm{CO}_{2}, 10 \% \mathrm{H}_{2}, 80 \% \\
\mathrm{~N}_{2}\end{array}$ & 3 & 7 & 72 & 12 & o & 0.8 & 23 & 94 \\
\hline $\begin{array}{l}4 \% \mathrm{O}_{2}, 8 \% \mathrm{CO}_{2}, 8 \% \mathrm{H}_{2} \text {, } \\
\quad 80 \% \mathrm{~N}_{2}{ }^{a}\end{array}$ & 6 & 3 & 33 & 42 & 3 & 1.1 & 23 & 87 \\
\hline
\end{tabular}

${ }^{a}$ Eighty percent of the air in the anaerobe jar was replaced with the anaerobe gas mixture, and the palladium catalyst was not included.

Fullerton, Calif.). Assays for indole production, reduction of nitrate and nitrite, and deamination of urea, arginine, lysine, and ornithine were performed as described by Cowan (1). The hydrolyses of esculin, gelatin, and starch and the reactions in milk were assayed by the method of Holdeman et al. (6).

Preparation of DNA. For DNA extraction, 10 strains were grown for 4 days at $37^{\circ} \mathrm{C}$ in broth con- taining $3 \%$ Trypticase soy broth, $1 \%$ yeast extract, $0.5 \%$ Tween 80 , and $0.1 \%$ sodium thioglycolate. For extraction of unlabeled DNA, about $700 \mathrm{ml}$ of a broth culture was centrifuged $\left(6,000 \mathrm{rpm}, 5^{\circ} \mathrm{C}, 20 \mathrm{~min}\right)$, and the cells were suspended in $20 \mathrm{ml}$ of lysing solution [50 mM tris ( hydroxymethyl) aminomethane - hydrochloride, $\mathrm{pH} 8.0$, and $50 \mu \mathrm{g}$ of pronase per ml]. Glass beads (50 $\mathrm{g}$; diameter, 0.17 to $0.18 \mathrm{~mm}$ ) were added, and the 
suspension was shaken with $\mathrm{CO}_{2}$ for $1.5 \mathrm{~min}$ four times in a Braun homogenizer (B. Braun Instruments, South San Francisco, Calif.). The cell lysates were then poured into a flask, and the beads were washed twice with $5 \mathrm{ml}$ of lysing solution. Supernatant fluids were combined and centrifuged at $3,000 \mathrm{rpm}$ for $10 \mathrm{~min}$. Sodium lauryl sulfate was added to a concentration of $1 \%$, and the lysates were treated successively with 1 volume of phenol [redistilled, $\mathrm{pH}$ adjusted to 8.0 with $\mathrm{NaOH}$, and equilibrated with $0.1 \mathrm{M}$ tris(hydroxymethyl)aminomethane-hydrochloride, $\mathrm{pH} 8.0$ ] and 1 volume of chloroform-isoamyl alcohol (24:1). After centrifugation at $3,000 \mathrm{rpm}$ for $5 \mathrm{~min}$ at room temperature, the procedure was repeated. DNA was then precipitated with 2 volumes of $95 \%$ ethanol in distilled water. After one ribonuclease treatment $(50 \mu \mathrm{g} / \mathrm{ml}$, $\left.60^{\circ} \mathrm{C}, 1 \mathrm{~h}\right)$ and one pronase treatment $\left(50 \mu \mathrm{g} / \mathrm{ml}, 37^{\circ} \mathrm{C}\right.$, $1 \mathrm{~h}$ ), the solution was subjected to two more cycles of successive treatments with phenol and chloroform. The DNA was finally precipitated with 2 volumes of 95\% ethanol.

Purified DNA was dialyzed against distilled water and sheared by ultrasonic treatment to an approximate molecular weight of $2.5 \times 10^{5}$. The DNA preparations were then adjusted to an $\mathrm{NaCl}$ concentration of $0.42 \mathrm{M}$ and stored frozen at $-20^{\circ} \mathrm{C}$.

Preparation of labeled DNA by nicktranslation. Labeled DNA was prepared from unsheared DNA $(7,8)$ purified by the procedure described above. A $1-\mu \mathrm{g}$ amount of DNA was dried at $37^{\circ} \mathrm{C}$ under a stream of compressed air, and a mixture of $9 \times 10^{2}$ pmol of guanosine triphosphate, and $1.8 \times 10^{2}$ pmol each of adenosine triphosphate, cytidine triphosphate, and $\left[{ }^{3} \mathrm{H}\right]$ thymidine triphosphate $(60 \mathrm{mCi} / \mathrm{mM}$; New England Nuclear Corp.) in 50\% ethanol in distilled water was dried under a vacuum. The nucleotides were redissolved in $10 \mu \mathrm{l}$ of a $10 \times$ salt mixture consisting of $100 \mu \mathrm{l}$ of $1 \mathrm{M}$ tris(hydroxymethyl)aminomethane-0.1 $\mathrm{M} \mathrm{MgCl}_{2}$ (pH 8) plus $100 \mu \mathrm{l}$ of a solution containing 1 mg of bovine serum albumin (Sigma Chemical Co., St. Louis, Mo.) per $\mathrm{ml}$ and $1.4 \mu \mathrm{l}$ of 2-mercaptoethanol and added to the dry DNA. Sterile distilled water was added such that the final volume of the reaction mixture was $100 \mu$ l. After a 10 -min preincubation at $15^{\circ} \mathrm{C}, 10$ to $20 \mathrm{U}$ of DNA polymerase I (catalog no. G315; (Worthington Biochemicals Corp., Freehold, N.J.) and $2 \mathrm{U}$ of deoxyribonuclease (Worthington) were added. The reaction was allowed to proceed at $15^{\circ} \mathrm{C}$ for $90 \mathrm{~min}$ and then was terminated by the addition of $40 \mu \mathrm{l}$ of $0.5 \mathrm{M}$ ethylenediaminetetraacetate. The reaction mixture was then extracted twice with a chloroform-isoamyl alcohol mixture (24:1) and loaded onto a G75 Sephadex column $(0.6$ by $7.5 \mathrm{~cm})$. The elution buffer was $1 \mathrm{mM}$ tris(hydroxymethyl)aminomethane- $0.25 \mathrm{mM}$ ethylenediaminetetraacetate, $\mathrm{pH} \mathrm{8.0.} \mathrm{A} \mathrm{total} \mathrm{of} 25$ fractions $(0.4 \mathrm{ml}$ each) were collected, and a 4- $\mu$ l sample of each fraction was spotted onto Whatman 3 MM filter paper disks, precipitated with cold trichloroacetic acid, and counted in a toluene-based cocktail in a Packard Tri-Carb liquid scintillation counter. Fractions containing the highest specific activity were pooled and dialyzed against 2.0 $\mathrm{mM} \mathrm{NaCl}$ for $66 \mathrm{~h}$. The labeled DNA was then sheared by sonication as described previously (2) and stored in $0.42 \mathrm{M} \mathrm{NaCl}$ at $-20^{\circ} \mathrm{C}$.
DNA reassociation and $S 1$ endonuclease assay. Hybrid DNA duplexes were prepared and analyzed with the single-strand-specific endonuclease S1 (2). Reassociation mixtures $(1 \mathrm{ml})$ were prepared by using $0.001 \mu \mathrm{g}$ of $\left[{ }^{3} \mathrm{H}\right] \mathrm{DNA}$ and $150 \mu \mathrm{g}$ of unlabeled DNA in $0.42 \mathrm{M} \mathrm{NaCl}$. Reassociation mixtures were boiled for $10 \mathrm{~min}$ and then incubated at $58^{\circ} \mathrm{C}$ for $16 \mathrm{~h}$. After incubation, four $0.2-\mathrm{ml}$ samples were removed and transferred to tubes containing $0.8 \mathrm{ml}$ of Sl reaction mixture, such that the final concentrations were $0.1 \mathrm{mM} \mathrm{ZnSO}_{4}, 0.15 \mathrm{M} \mathrm{NaCl}, 0.03 \mathrm{M}$ sodium acetate buffer, $\mathrm{pH} \mathrm{4.5}$, and $20 \mu \mathrm{g}$ of sheared denatured calf thymus DNA (Sigma type V) per $\mathrm{ml}$. Two tubes were treated with 500 endonuclease (Miles Laboratories, Elkhart, Ind., Inc.) units of $\mathrm{S} 1$ for $20 \mathrm{~min}$ at $50^{\circ} \mathrm{C}$. The other tubes were treated identically but without the addition of S1. The S1 reaction was terminated, and the DNA was precipitated with $20 \%$ cold trichloroacetic acid to a final concentration of $5 \%$. The trichloroacetic acid precipitates were collected on membrane filters (type HA 2500; Millipore Corp., Bedford, Mass.) and dried at $70^{\circ} \mathrm{C}$. The radioactivity of each filter was determined as described above. The degree of polynucleotide sequence homology was calculated by determining the ratio of the average counts between the S1-treated and untreated samples after background subtraction. Results were then normalized to the homologous reassociation values after correction for selfreassociation of the labeled DNA.

\section{RESULTS AND DISCUSSION}

As previously reported (4), cells of $P$. saccharolyticus are gram-positive cocci occurring in irregular masses or, occasionally, in tetrads or pairs. Colonies on Columbia blood agar demonstrated variability within a single strain in terms of contour, opacity, and surface texture. However, no biochemical or other difference could be found to correlate with the variations in colony morphology. All strains grew well at $48 \mathrm{~h}$ on solid medium (Columbia blood agar) incubated anaerobically under an atmosphere of $10 \%$ hydrogen, $10 \%$ carbon dioxide, and $80 \%$ nitrogen. Of the 23 strains, 17 showed growth at 4 days under aerobic conditions; 2 additional strains required carbon dioxide for aerobic growth. In comparative tests (Table 2), colonies were larger after anaerobic incubation than they were in the presence of air with or without added $\mathrm{CO}_{2}$. However, maximum colony size on Columbia blood agar but not on Trypticase soy-yeast extract agar was obtained by growth in an atmosphere of $4 \%$ oxygen, $8 \%$ hydrogen, $8 \%$ carbon dioxide, and $80 \%$ nitrogen, which was achieved by evacuating only $80 \%$ of the air from an anaerobe jar, replacing it with the above anaerobic gas mixture, and incubating in the absence of palladium catalyst. If pure nitrogen was used for replacement rather than the anaerobic gas mixture, the growth characteristics were approximately the same as those obtained by incubation in air. 
Hence, the stimulatory effect of reduced oxygen concentration appeared to require the presence of $\mathrm{H}_{2}$ or $\mathrm{CO}_{2}$ or both. Efforts to explain this phenomenon are being continued in our laboratory.

All 23 strains examined produced acid from glycerol, glucose, fructose, and mannose. The final $\mathrm{pH}$ averaged 5.3 , and the $\mathrm{pH}$ range was 5.0 to 5.6. No strains produced acid from the following compounds: arabinose, ribose, xylose, rhamnose, galactose, esculin, amygdalin, salicin, cellobiose, lactose, maltose, sucrose, trehalose, melezitose, raffinose, inulin, starch, mannitol, sorbitol, adonitol, and glycogen. There was no observable hydrolysis of starch, esculin, or gelatin. Nitrate reduction was variable at 4 days but positive for all strains at 10 days. Indole was not produced. Ammonia was consistently produced from arginine. With 21 of the 23 strains examined, addition of $1 \%$ arginine to the basal medium induced an adherent cell growth characterized as a thick, sticky sediment that was not easily dispersed on mixing. The exceptions to the latter phenomenon were strains $3-0-15$ and 3-0-23.

It could be concluded from analyses of these results that $P$. saccharolyticus strains appear to form a very homogeneous group on the basis of phenotypic characteristics.

In the studies of DNA homology we initially determined that the guanine plus cytosine composition of $P$. saccharolyticus DNA was about $33 \mathrm{~mol} \%$. As a consequence, we chose a reassociation temperature of $58^{\circ} \mathrm{C}$ to perform the DNA hybridization reactions.

Polynucleotide sequence relationships were assessed in strains of $P$. saccharolyticus isolated from different sources. The conditions of reassociation were sufficiently stringent to approximate close register of the hybrid strands, as the homologous reassociation reaction ranged between 71 and $93 \%$. Some experiments were carried out at higher reassociation temperatures (up to $68^{\circ} \mathrm{C}$ ) and resulted in much lower homologous reassociation values, as expected from the low guanine plus cytosine contents of the $P$. saccharolyticus strains (data not shown).

Results of the DNA hybridizations expressed as percent homology, are shown in Table 3. When labeled reference DNA from $P$. saccharolyticus ATCC 14953 was used, it was apparent that $P$. saccharolyticus strains isolated from different sources form a very tight homology group.

The recent data (3) showing the common occurrence of $P$. saccharolyticus on normal skin strongly suggest that this organism has gone unrecognized in past studies of normal cuta-
TABLE 3. DNA hybridization reactions with $\left[{ }^{3} \mathrm{H}\right]$ labeled DNA from P. saccharolyticus ATCC 14953

\begin{tabular}{|c|c|}
\hline Strain & $\begin{array}{c}\text { Relative } \\
\text { DNA sequence } \\
\text { homology" }\end{array}$ \\
\hline \multicolumn{2}{|l|}{ P. saccharolyticus } \\
\hline ATCC 14953 & 100 \\
\hline $3-0-1 \ldots \ldots \ldots \ldots \ldots \ldots \ldots \ldots \ldots$ & 98 \\
\hline$\ldots \ldots \ldots \ldots \ldots \ldots \ldots$ & 94 \\
\hline $3-0-8$ & 99 \\
\hline $3-0-10$ & 95 \\
\hline $3-0-12$ & 95 \\
\hline $3-0-24$ & 99 \\
\hline $3-0-27$ & 100 \\
\hline $3-0-29$ & 94 \\
\hline 3-0-30 $\ldots \ldots \ldots$ & 93 \\
\hline E. coli $\mathrm{K}-12$ W1485-1 . . . & 4 \\
\hline
\end{tabular}

${ }^{a}$ The degree of DNA-DNA duplex formation was assessed by the $S 1$ endonuclease method (2). The actual extent of reassociation for the homologous reaction averaged $82 \%$. All other reactions were normalized to this value set at $100 \%$. Each value shown is an average of three separate determinations.

neous flora. This organism is obviously not a common cause of infection, but it will be important to determine whether it has been similarly missed in clinical laboratories and whether it is one of the opportunistic pathogens causing occasional infections in vulnerable patients.

The results of physiological tests and DNA analysis show that $P$. saccharolyticus is a unique and distinct species. The appropriate generic classification of $P$. saccharolyticus remains to be determined.

$P$. saccharolyticus differs from other peptococci in its greater fermentative capability. The fact that lactic acid is not a significant product of its fermentation of glucose constitutes a substantial difference from the staphylococci and streptococci and probably from members of the genus Aerococcus since $A$. viridans ATCC 11563 produced lactic acid in our tests. The unusual preference for an atmosphere with a reduced $\mathrm{O}_{2}$ concentration supplemented by $\mathrm{H}_{2}$ or $\mathrm{CO}_{2}$ or both requires further study before its taxonomic, metabolic, and ecological significance can be evaluated. Schleifer and his associates (10) have found similarities in the structures of the cell walls of $P$. saccharolyticus and staphylococci. Our preliminary results indicate that $P$. saccharolyticus DNA hybridized at a level of about 25 to $30 \%$ with DNA from some coagulase-negative staphylococci, thus suggesting a low, although significant (compare with the 5\% value obtained from Escherichia coli), degree of relatedness between these two groups of bacteria. Kilpper and Schleifer (R. Kilpper and K. H. Schleifer, Abstr. XII Int. Congr. Microbiol. Mu- 
nich, abstr. no. C-6, 1978) recently reported a similar level of DNA homology between $P$. saccharolyticus and some coagulase-negative staphylococci. They reported no such relationship with several other species of Peptococcus or with organisms in several other genera of gram-positive cocci. Until additional studies of this sort are published in full, the generic classification of this organism must be considered tentative, and the only name available for it remains Peptococcus saccharolyticus.

\section{ACKNOWLEDGMENTS}

This project was supported in part by Public Health Service grants DE-02600 and AM 22082 from the National Institutes of Health and by National Science Foundation grant PCM 7514174-A02.

\section{REPRINT REQUESTS}

Address reprint requests to: $\mathrm{Dr}$. Charles A. Evans, Department of Microbiology and Immunology SC-42, University of Washington School of Medicine, Seattle, WA 98195.

\section{LITERATURE CITED}

1. Cowan, S. T. 1974. Cowan and Steel's manual for the identification of medical bacteria. Cambridge University Press, London.
2. Crosa, J. H., D. J. Brenner, and S. Falkow. 1973. Use of a single-strand specific nuclease for analysis of bacterial and plasmid deoxyribonucleic acid homo- and heteroduplexes. J. Bacteriol. 115:904-911.

3. Evans, C. A., and K. L. Mattern. 1978. Individual differences in the bacterial flora of the skin of the forehead: Peptococcus saccharolyticus. J. Invest. Dermatol. 71. 152-153.

4. Evans, C. A., K. L. Mattern, and S. L. Hallam. 1978 Isolation and identification of Peptococcus saccharolyticus from human skin. J. Clin. Microbiol. 7:261-264.

5. Foubert, E. L., Jr., and H. C. Douglas. 1948. Studies on the anaerobic micrococci. I. Taxonomic considerations. J. Bacteriol. 56:25-34.

6. Holdeman, L. V., E. P. Cato, and W. E. C. Moore (ed.). 1977. Anaerobe laboratory manual, 4th ed. Virginia Polytechnic Institute and State University, Blacksburg.

7. Kelly, R. B., N. R. Cozzarelli, M. P. Deutscher, I. R. Lehman, and A. Kornberg. 1970. Enzymatic synthesis of deoxyribonucleic acid. XXXII. Replication of duplex deoxyribonucleic acid by polymerase at a single strand break. J. Biol. Chem. 245:39-45.

8. Maniatis, T., A. Jeffrey, and D. G. Kleid. 1975. Nucleotide sequence of the rightward operator of phage $\lambda$. Proc. Natl. Acad. Sci. U.S.A. 72:1184-1188.

9. Rogosa, M. 1974. Genus I, Peptococcus Kluyver and van Niel 1936, p. 518-522. In R. E. Buchanan and N. E. Gibbons (ed.), Bergey's manual of determinative bacteriology, 8th ed. The Williams \& Wilkins Co., Baltimore.

10. Schleifer, K. H., and E. Nimmerman. 1973. Peptidoglycan types of strains of the genus Peptococcus. Arch. Mikrobiol. 93:245-258. 